Policy Research Working Paper 2246

\section{Infrastructure's Contribution to Aggregate Output}

David Canning
Of the major kinds of physical infrastructure, electricity generating capacity has roughly the same marginal productuvity as physıcal capitai as a whole. So have roads-

plus-rail, globally and in lower-income countries. Telephones, however, and transport routes in higher-income countries, have higher marginal productivity than other kinds of capital.

The World Bank

Development Research Group

Public Economics

November 1999 


\section{Summary findings}

Using panel data for a cross-section of countries, Canning estimates an aggregate production function that includes infrastructure capital. He finds that:

- The productivity of physical and human capital is close to the levels suggested by microeconomic evidence on their private returns.

- Electricity generating capacity and transportation networks have roughly the same marginal productivity as capital as a whole.
- Telephone networks appear to show higher marginal productivity than other types of capital.

Panel data cointegration methods used in estimation take account of the nonstationary nature of the data, are robust to reverse causation, and allow for different levels of productivity and different short-run business-cycle and multiplier relationships across countries.

This paper - a product of Public Economics, Development Research Group - is part of a larger effort in the group to study the impact of public expenditures. The study was funded by the Bank's Research Support Budget under the research project "Infrastructure and Growth: A Multicountry Panel Study" (RPO 680-89). Copies of the paper are available free from the World Bank, 1818 H Street, NW, Washington, DC 20433. Please contact Hedy Sladovich, room MC2-609, telephone 202473-7698, fax 202-522-1154, email address hsladovich@worldbank.org. Policy Research Working Papers are also posted on the Web at www.worldbank.org/research/workingpapers. The author may be contacted at d.canning@qub.ac.uk. November 1999. (14 pages)

The Policy Research Working Paper Series disseminates the findings of work in progress to encourage the exchange of ideas about development issues. An objective of the series is to get the findings out quickly, even if the presentations are less than fully polished. The papers carry the names of the authors and should be cited accordingly. The findings, interpretations, and conclusions expressed in this paper are entirely those of the authors. They do not necessarily represent the view of the World Bank, its Executive Directors, or the countries they represent. 


\title{
Infrastructure's Contribution to Aggregate Output
}

\author{
David Canning \\ Queen's University, Belfast \\ Harvard University, Department of Economics \\ E-mail: dcanning@qub.ac.uk
}

David Canning is a consultant of the World Bank. He thanks Esra Bennathan, Peter Pedroni, Michael Moore, and Peter Dunne for their comments. This paper has been produced as part of a World Bank research project: Infrastructure and Growth: A MultiCountry Panel Study (RPO 680-89). 



\section{Introduction}

A central question in the theory of economic growth is the contribution of the different factors of production to aggregate output. Direct evidence of this contribution comes from the rewards earned by the factors, which in a perfectly competitive economy will equal their marginal products. The problem with this approach is that factor inputs may generate spillovers or externalities which make their marginal social benefit, and effect on aggregate output exceed (or fall short of) their marginal private benefit as measured by the rewards they earn. By looking at their effect on aggregate output directly we can measure the size of these externalities.

This has important policy implications in terms of the appropriate level of investment in different sectors, since the market will tend to provide capital in response to price signals, which reflect private benefits and ignore externalities. If there are large externalities we may require government intervention to achieve more efficient allocation of resources, though government intervention itself has its own costs. The aim of this paper is to measure the aggregate output effect of different types of infrastructure capital.

The fact that infrastructure services are often provided by the public sector means they are often not priced at all, or are rationed, and we have difficulty even in estimating the private productivity of infrastructure capital. Internal rates of return estimated for specific infrastructure projects reported by the World Bank (1994) for road building, electricity supply, telecommunications, water and sanitation projects are roughly in line with the rates of return on private capital. In addition, the rates of return on public sector projects should be adjusted downwards if the government has to raise funds through distortionary taxation. This suggests that there is no under provision of infrastructure in general.

While these rates of return estimates are based on cost benefit analysis, and so should take account of social benefits and not just private benefits, in practice there are great difficulties in estimating all the externalities that may be present. For example, transportation and communications infrastructure may link markets, and increase the degree of competition. Two monopolists in separate markets may lower their prices once the markets become linked, without any movement of the good between markets actually taking place. Alternatively, communication systems may increase the rate of diffusion of technology, as a pure externality, raising output but without necessarily raising the demand for infrastructure use.

Our approach to estimating the productivity of infrastructure will be to estimate an aggregate production function incorporating labor, physical capital, human capital (education) and our infrastructure variables, the number of telephones, electricity generating capacity and kilometers of transportation routes (paved roads and railroads). We use a panel of annual cross-country data for the period 1960-90. There are important 
precedents for our approach. Mankiw, Romer and Weil (1992) estimate a cross-country production function for physical capital and human capital (the augmented Solow model). Aschauer (1989), Holtz-Eakin (1994), Garcia-Mila, McGuire and Porter (1996) and others have estimated production function models including infrastructure capital across regions of the United States. Gramlich (1994) provides a survey of efforts to measure the aggregate effects of infrastructure.

Aggregate output depends on inputs and the productivity with which these inputs are used. A problem in our estimation is that we lack independent data on total factor productivity across countries. While Mankiw, Romer and Weil (1992) assume a common worldwide technology, it seems clear that there are unexplained differences in total factor productivity across the world (Prescott 1998). We model total factor productivity as a country specific constant, plus common worldwide growth each year. The use of such fixed effects to capture differences in total factor productivity fails to explain these differences, but does render our estimates of the productivity of capital robust to such differences.

While it is easy to model the production function, the problem of reverse causality makes estimation potentially very difficult. Capital inputs may determine output, but output may have a feedback into capital accumulation.

One estimation procedure would be to estimate a panel growth regression and take the implied steady state to be the production function. This, however, requires the estimation of a dynamic panel with fixed effects, which raises econometric problems. While dynamic panel estimators, such as those used by Islam (1995), are consistent as the number of time periods becomes large, they tend to have poor small sample properties. In particular, the generalized method moments estimators used by Caselli, Esquivel and Lefort (1996) has poor finite sample properties because of the weakness of the instrumental variables. On the other hand, the system estimator proposed by Arellano and Bover (1995), and used by Bond Hoeffler and Temple (1999) gives implausible parameter estimates for the production function. Our approach to the problem of estimation is to note that output per worker, and our capital stocks per worker, are nonstationary. It follows that the production function may represent a long-run cointegrating relationship. In this case we can use the panel data cointegration methods of Kao and Chiang (1997). These methods allow each country to have its own short-run dynamic interactions and feedbacks, to give consistent estimates of the parameters of the production function that are robust to reverse causality. They also allow the construction of valid hypothesis tests on the estimated parameters.

Even with cointegration, there is a possibility that what we are estimating is the reverse causality between income levels and inputs, not the production function. If a constant proportion of output is invested, capital and output will move together even if capital has no productivity. We identify the system by assuming that the production 
function holds for all countries, while the relationship between investment and income varies across countries. This implies that in a time series for an individual country there may be two long-run relationships between inputs and outputs, one being the production function and the other, the investment relationship. However, when we pool across countries, only the production function relationship will hold uniformly, with the different investment behavior of different countries leading to different steady state outcomes across countries.

In this framework, simple ordinary least square regressions give consistent estimates of the production function. We can improve efficiency by including in the model parameters designed to capture business cycle multiplier and accelerator effects that may be present in the data. While the same production function is assumed to hold worldwide, these short-run effects are allowed to vary across countries.

Using this approach, we find that the elasticity of output with respect to physical capital is around 0.37 , which is in line with previous macroeconomic estimates and with estimates based on the returns capital earns. For human capital in the form of education we find an elasticity of around 0.1 , which is substantially lower than that estimated by Mankiw Romer and Weil. However, this figure is close to the elasticity found by Klenow and Rodriguez-Clare (1997), and Hall and Jones (1998) when they calibrate an augmented Solow model with microeconomic evidence on the returns to education from Psacharopoulos $(1985,1994)$.

For infrastructure we find no significant impact of electricity generating capacity, or transportation infrastructure. Since infrastructure capital is already included in our physical capital stock, this implies that these types of infrastructure have the normal productivity effect of capital as a whole. This makes the very large impact we find for telephones surprising. We find the elasticity of output with respect to the telephone stock to be around 0.14 , holding constant the overall stock of capital; that is, we find a large impact from increasing the telephone stock and removing an equal amount of investment in other physical capital. This result suggests that there is a large externality to telecommunications infrastructure and this result persists when we split the sample up into developed and less developed countries. For developed countries we also find that transportation routes appear to have above average productivity. The idea that the productivity of infrastructure varies with the level of development, and perhaps with other factors, will be examined in more detail in future work

This paper only looks at the productivity of infrastructure. The fact that telephones have higher productivity than other types of capital (as do transportation routes in developed countries) raises the presumption that these types of capital are under supplied, and that transferring investment from other types of capital to telecommunications infrastructure would raise output. This simple interpretation of our results relies on the relative prices of each type of capital being the same across countries. In practice, to 
determine if countries are above or below the optimal infrastructure level we need to compare the marginal productivity estimates we obtain here with country specific costs of infrastructure; this will be carried out in a future paper. Canning and Pedroni (1999) find evidence of great heterogeneity across countries in terms of where they stand relative to the optimal infrastructure level.

\section{The Model}

We assume that output is determined by a Cobb Douglas production function of the form.

$$
Y_{i t}=A_{i t} K_{i t}^{\alpha} H_{i t}^{\beta} X_{i t}^{\gamma} L_{i t}^{1-\alpha-\beta-\gamma} U_{i t}
$$

where $\mathrm{Y}$ is total output $A$ is total factor productivity, $K$ is physical capital, $H$ is human capital, $X$ is infrastructure capital, $L$ is labor and $U$ is an error term. Throughout, we use $i$ to index countries and $t$ to index time. We assume constant returns to scale, so that the sum of the exponents is one. This seems reasonable since there is little evidence of a pure size effect on a country's output level. In addition, we assume that total factor productivity takes the form $\log A_{i t}=a_{i}+b_{t}$, which we can regard as a country fixed effect, indexed by $i$, and worldwide growth of productivity, indexed by $t$. Dividing through by $L$, and taking logs, we can derive

$$
y_{i t}=a_{i}+b_{t}+\alpha k_{i t}+\beta h_{i t}+\gamma x_{i t}+u_{i t}
$$

where capital stocks, and output, are now in $\log$ per worker terms and $u_{i t}=\log U_{i t}$.

For output per worker we use purchasing power parity GDP per worker (chain index) from the Penn World Tables 5.6 (see Summers and Heston 1991). Physical capital is constructed using a perpetual inventory method. Assuming a capital-output ratio of three in the base year (usually 1950) we update each year's capital stock by adding investment (from Penn World Tables 5.6) and subtracting as depreciation, 7 percent of the existing capital stock. Our results are remarkably robust to variations in the initial choice of capital-output ratio and the depreciation rate. Human capital per worker is taken to be the average years of schooling of the workforce, from Barro and Lee (1993). Since these human capital data are available only ever every five years, we interpolate to give annual data.

We use three infrastructure capital stock variables based on direct measurement of the capital stocks. These are the number of telephones, kilowatts of electricity generating capacity, and the total length of transport routes, measured as the sum of paved roads and railway line length. The infrastructure figures are the processed data from Canning (1998). While these physical measurements are likely to be better than estimates based on investment figures (see Pritchett 1996) they do not reflect quality differences in 
infrastructure across countries and over time. These differences may be important (Hulten 1997).

A problem with interpreting equations (1) and (2) comes from the fact that infrastructure capital appears twice, once on its own in the form of $X$ but also as a part of aggregate capital, $K$. Let $Z$ be non-infrastructure capital, then we can write

$$
K_{i t}=\frac{Z_{i t} p_{z}+X_{i t} p_{x}}{p_{k}}
$$

where $p_{z}, p_{x}$ and $p_{k}$ are the world average prices of $Z, X$, and $K$ respectively. The aggregate capital stock is the value of total capital (we sum the volume of each type of capital times its price) divided by the price of capital. To construct these volume measures we use world prices of investment goods; all prices are expressed relative to output, which is taken to be the numeraire.

In principle, it is strange to have prices appear in a production function. However, when we use an aggregate production function we assume that meaningful aggregates of the various inputs into production can be constructed. In theory, this requires adding different types of capital together, weighting each by its productivity; in practice, we weigh each type of capital by its price.

Using equation (3) it is easy to derive

$$
\frac{M P X_{i t}}{p_{i x}}=\frac{M P Z_{i t}}{p_{i z}} \frac{p_{x}}{p_{i x}} \frac{p_{i z}}{p_{z}}+\gamma \frac{Y_{i t} / X_{i t}}{p_{i x}}
$$

$M P X$ and $M P Z$ are the marginal products of $X$ and $Z$ respectively. The left-hand side of equation (4) represents the increase in output obtained by diverting one unit of consumption to infrastructure investment, at local prices $p_{i x}$. The two terms on the right hand side of equation (4) represent the productivity contribution of infrastructure through its effect on aggregate capital and through its own additional effect. If $p_{i x} / p_{x}=p_{i z} / p_{z}$, so that the relative prices of the two types of capital in country i equal world relative prices, equation (4) simplifies to

$$
\frac{M P X_{i t}}{p_{i x}}=\frac{M P Z_{i t}}{p_{i z}}+\gamma \frac{Y_{i t} / X_{i t}}{p_{i x}}
$$

In this case, the productivity effect of investing in infrastructure equals the productivity of an equal amount of investment in other capital, plus a term which can be either positive or negative depending on the sign of $\gamma$. It follows that, for countries whose relative prices are not too divergent from world prices, investment in infrastructure is more 
productive than other types of capital if $\gamma>0$, less productive than other types of capital if $\gamma<0$ and just as productive as other types of capital if $\gamma=0$.

A difficulty with estimating the production function as set out above is the possibility of a correlation between the error terms and the capital stocks, due to reverse causation. This makes it unclear if we are estimating the contribution of capital to output or the effect of output on capital accumulation. Mankiw, Romer and Weil (1992) replace the capital per worker terms with investment rates, arguing that investment rates may be considered as exogenous. While this is true in the simple Solow growth model, output shocks will affect the marginal product of each type of capital, and in an optimizing model, such as the Ramsey model, this may induce effects on the investment rate.

Our approach to this problem is to argue that output per worker, and our capital stock per worker variables, are non-stationary. If the production function we model correctly describes the relationship between technical progress, capital per worker, and output per worker, we should have a cointegrating equation. That is, the residuals from equation (2) should be stationary. If this is the case we can estimate the relationship by relatively straightforward means.

If we omit a relevant type of capital, or do not correctly model the evolution of total factor productivity, our estimated growth equation may have a missing non-stationary component, and we will not have cointegration. In time series analysis, estimating a relationship between non-stationary variables that are not cointegrated gives rise to the problem of spurious regression; the error term in the regression is non stationary, producing a high degree of "noise" in the relationship, and inconsistent parameter estimates. However, in panel data analysis, Kao (1997) shows that parameter estimates in a fixed effects model are consistent even if the relationship being estimated is not a cointegrating relationship. In a panel, pooling in the cross section dimension attenuates the noise in the time series dimension.

Even if the production function is a cointegrating relationship, there are substantial estimation problems. Under cointegration, the ordinary least squares estimation of equation (2) gives consistent parameter estimates, though they are biased in samples taken over a finite time span. In addition, if we were to ignore the non-stationarity, proceeding instead to estimate the relationship on the assumption of stationarity-the usual case under OLS - the standard errors of the parameter estimates obtained often will be much too small. This implies that simple ordinary least squares in levels may lead to a tendency to find statistically significant coefficient estimates when in fact there is no relationship. On the other hand, simply taking first differences of all the variables, to eliminate non-stationarity, results in an estimation that relates short-run capital accumulation to short-run changes in output and may thus fail to capture the long-run relationship in levels that is at the heart of the production function. 
The bias in ordinary least squares estimation in levels is introduced by short-run feedbacks between the disturbances in the production function and capital accumulation. Kao and Chiang (1997) show that by estimating an equation of the type

$$
y_{i t}=a_{i}+b_{t}+\alpha k_{i t}+\beta h_{i t}+\gamma x_{i t}+\sum_{s=-k}^{k} \phi_{i s} \Delta k_{i t+s}+\sum_{s=-k}^{k} \varphi_{i s} \Delta h_{i t+s}+\sum_{s=-k}^{k} \theta_{i s} \Delta x_{i t+s}+u_{i t}
$$

we can obtain consistent, unbiased estimates of the long-run parameters. The addition of the $k$ lags and $s$ leads of the capital stock growth rates (indexed by $s$ ), in addition to the current growth rate (i.e., $s=0$ ), corrects for short-run dynamic effects in both directions. Note that the coefficients on the capital growth rates vary across countries; this allows each country to have its own short-run adjustment dynamics. In addition, Kao and Chiang show how to construct a long-run covariance matrix to produce asymptotically valid hypothesis tests on the parameter estimates produced by this regression. This is the technique we will employ here.

Even if the production function is a cointegrating relationship there remains the problem that the technique is only valid if there are no further cointegrating relationships in the data. To some extent, this problem is taken care of in the estimation procedure. Cointegration of the capital stock variables implies perfect multi-collinearity of our explanatory variables asymptotically. This will show up in very large standard errors on our estimates since the data will be unable to determine which variables are responsible for explanatory power of the regression. This underlines the importance of using hypothesis tests that are valid given the non-stationary nature of the data.

One possible source for further cointegrating relationships in the data comes from the relationship between income and investment. If the production function and investment behavior of each country were identical each country would have exactly the same outcome and we would have insufficient variation between countries to identify any relationships. We require variations in inputs to identify the production function relationship. One reason for cross country differences in savings and investment behavior are differences in distortions, such as taxes and corruption, and differences in the risk of expropriation. Chari, Kehoe, and McGratten (1996) argue that these factors can explain the cross-country variation in capital accumulation and output that we actually observe. The maintained assumption throughout this paper is that the production function represents a cointegrating relationship between in puts and outputs that holds worldwide, while if there are any long-run feedbacks from income to capital stocks via investment, these vary across countries. 


\section{Tests for Unit Roots}

We begin by carrying out panel unit root tests on output per worker and each of our capital stock variables. One approach would be to examine the time series of each country separately and test if it is a unit root, but such tests have notoriously low power. An alternative approach is to follow Im, Pesaran, and Shin (1995), who develop a panel unit root test for the joint null hypothesis that every time series in the panel is non stationary. This approach is to run a standard augmented Dickey-Fuller unit root test for each country and average the $t$-values of the test statistic found. If the data from each country are statistically independent then, under the null, we can regard the average $t$-value as the average of independent random draws from a distribution with known expected value and variance (that is, those for a non-stationary series). This provides a much more powerful test of the unit root hypothesis than the usual single time series test. Note that, by running each augmented Dickey-Fuller regression separately before averaging, we implicitly allow each country to have its own short-run dynamics.

For income per worker and electricity generating capacity per worker we use countries that have a complete data set over the period 1950-90. To keep the number of countries relatively large, I have take the period 1960-90 in the case of telephones, human capital, and transportation routes per worker. A similar period is used for physical capital per worker. Using data only from 1960 onwards helps to avoid distortions caused by the imposition of a fixed capital-output ratio in 1950 when we use the perpetual inventory method.

Im, Pesaran, and Shin recommend the removal of any common time effects by first regressing the variable on a set of time dummies and taking the residuals. This reduces the risk of correlation across countries, and is carried out for each of our variables. In each case (except for education) the augmented Dickey Fuller regression, with a constant and time trend, and 5 augmenting lags, is run using the residuals after common time effects have been removed. Results are reported in table 1 .

Table 1. Panel Unit Root Tests for Levels (common time dummies removed from all variables)

\begin{tabular}{lcccc}
\hline Variable & Period & $\begin{array}{c}\text { Number of } \\
\text { countries }\end{array}$ & $\begin{array}{c}\text { Average } \\
\text { adf }\end{array}$ & $\begin{array}{c}\text { Test } \\
\text { Statistic }\end{array}$ \\
\hline log GDP per worker & $1950-90$ & 57 & -1.90 & 0.73 \\
$\log$ capital per worker & $1960-90$ & 104 & -1.93 & -0.35 \\
Log education per worker & $1960-90$ & 103 & -2.48 & -1.46 \\
Log telephones per worker & $1960-90$ & 67 & -1.39 & -0.28 \\
$\log$ EGC per worker & $1950-90$ & 50 & -1.79 & 1.50 \\
$\log$ routes per worker & $1960-90$ & 28 & -1.56 & -0.08 \\
\hline
\end{tabular}

Note: Time trend included. Test statistic is $\mathrm{N}(0,1)$ under the null of non-stationarity. Large negative values indicate stationarity. 
For example, in the case of log GDP per worker we have 57 countries that have a complete data set over the period 1950-90. Running 57 augmented Dickey-Fuller regressions, after removing common time effects, gives an average $t$-value of -1.90 . Under the null of non-stationarity, the $t$-value in each country has an expected value of -1.992 with a variance of 0.907 (as tabulated by Im, Pesaran, and Shin). The test statistic, calculated as the difference between the average $t$-value and this expected value, and adjusted for the variance, has a $\mathrm{N}(0,1)$ distribution under the null of non-stationarity, with large negative values indicating stationarity (since only negative values indicate stationarity we use a one-tailed test). It is clear that we cannot reject a unit root for log GDP per capita. Similarly, it is clear we cannot reject a unit root for any of our variables in levels.

The one exception to this procedure is in the case of education, where we have data at five year intervals rather than annually. In this case we construct simple Dickey-Fuller statistics for each country, testing for a unit root against trend stationarity, taking the time period to be five years not allowing for any auto-correlation. While auto-correlation should not be such a big problem with such long periods, the individual unit root tests are now being carried out on only 7 observations, giving 6 data points per country. However, Pierce and Snell (1995) show that the power of unit root tests depends on the time span of the sample rather than the number of observations. In addition, Pedroni (1997) shows by a Monte Carlo study that the panel unit root test has very high power even with very short panels if the cross section dimension is reasonably large. These results imply that using a five year interval for observations may not reduce the power of our unit root tests by much. Im, Pesaran, and Shin (1995) do not give critical values for such short panels; critical values for this case are calculated using their methodology.

In order to check that the variables are I(1) we also test for stationarity in first differences. Results of this test are reported in table 2. In these cases the alternative hypothesis is stationarity around a constant since any time trend in levels will be removed by differencing. In every case we reject a unit root in first differences in favor of stationarity as the 5 percent significance level. In what follows we assume all our series are non-stationary but are integrated of order one.

We could also test for cointegration between our series. However, given the results in Kao (1997) our coefficient estimates will be consistent whether or not we have a cointegrating relationship. The real issue is the usual one; our estimates will be reliable provided the model being estimated represents the true relationship generating the data. An omitted variable will, as always, produce a bias in our estimates. The key question is really whether the error term is independent "noise" or the product of miss-specification. This question remains crucial for our panel estimates, whether or not the error term is non-stationary. 
Table 2. Panel Unit Root Tests for Differences

(common time dummies removed from all variables)

\begin{tabular}{lcccc}
\hline Variable & Period & $\begin{array}{c}\text { Number of } \\
\text { countries }\end{array}$ & $\begin{array}{c}\text { Average } \\
\text { adf }\end{array}$ & $\begin{array}{c}\text { Test } \\
\text { Statistic }\end{array}$ \\
\hline$\Delta \log$ GDP per worker & $1951-90$ & 57 & -2.11 & -5.55 \\
$\Delta \log$ capital per worker & $1961-90$ & 104 & -1.63 & -2.99 \\
$\Delta \log$ education per worker & $1961-90$ & 103 & -2.96 & -8.63 \\
$\Delta \log$ telephones per worker & $1961-90$ & 67 & -1.63 & -3.02 \\
$\Delta \log$ EGC per worker & $1951-90$ & 50 & -2.37 & -6.99 \\
$\Delta \log$ routes per worker & $1961-90$ & 28 & -1.66 & -1.72 \\
\hline
\end{tabular}

Note: No time trend. Test statistic is $\mathrm{N}(0,1)$ under the null of non-stationarity. Large negative values indicate stationarity.

\section{Results}

We begin our estimation of the production function by looking only at the effects of physical and human capital. These results are shown in table 3. We select countries where we have a complete data set on the relevant variables over the period 1960-90. We begin in column (1) of table 3 with ordinary least squares regressions assuming a common worldwide level of total factor productivity that changes over time. We find a very high effect of physical capital but little effect of human capital. Adding fixed effects in column (2), which allows each country to have its own level of total factor productivity, as in equation (2), substantially reduces the impact of physical capital and raises the impact of human capital. While the coefficient estimates in columns and (1) and (2) are consistent under the assumption that the production function being estimated is the true relationship, the $t$-ratios calculated under ordinary least squares are not valid and are not reported. These estimated $t$-ratios are all very high, but spurious. For all our regressions, the $\mathrm{R}^{2}$ is very close to one and is not reported.

In column (3) we provide estimates using the regression set out in equation (6). This employs country specific short-run dynamics, as well as country fixed effects and world wide time dummies. We add the current capital stock growth rates, plus one lag and one lead. The $t$ ratios are computed using the long-run variance covariance matrix of residuals and first differences of the explanatory variables (estimated using a Bartlett kernel with a lag truncation parameter of 3 ) and are asymptotically normal with distribution $\mathrm{N}(0,1)$. These $t$-ratios are consistent under the assumption that the relationship is cointegrated; that is, that we have not omitted any long-run, non-stationary, factors that drive economic growth. Note that our parameter estimates do not change substantially from the simple ordinary least square estimates in levels with fixed effects. This implies that in practice the small sample bias in the ordinary least squares estimator may not be very great.

In column (4) of table 3 we report estimates based short-run dynamics incorporating the current, together with two lags and two leads, of each capital stock growth rate. This 
allows for richer short-run feedback effects but has little impact on our parameter estimates or the estimated $t$-ratios. For comparison purposes we have constrained all estimates in table 3 to cover the same data set.

Table 3. The Production Function with Physical and Human Capital (dependent variable: log GDP per worker, 1960-90)

\begin{tabular}{lcccc}
\hline Total factor productivity & Year dummies & $\begin{array}{c}\text { Year dummies, } \\
\text { fixed effects }\end{array}$ & $\begin{array}{c}\text { Year dummies, } \\
\text { fixed effects }\end{array}$ & $\begin{array}{c}\text { Year dummies, } \\
\text { fixed effects }\end{array}$ \\
\hline Short-run dynamics & & & 2 lags, 1 lead & 3 lags, 2 leads \\
Log capital per worker & 0.714 & 0.470 & 0.435 & 0.431 \\
& & & $(15.8)$ & $(14.6)$ \\
Log human capital per & 0.075 & 0.190 & 0.127 & 0.121 \\
$\quad$ & & & $(4.62)$ & $(4.09)$ \\
Worker & 82 & 82 & 82 & 82 \\
Obuntries & 2,132 & 2,132 & 2,132 & 2,132 \\
\hline
\end{tabular}

Note: $t$-ratios in parentheses are calculated based on the long-run auto-covariance matrix and are asymptotically $\mathrm{N}(0,1)$.

The coefficients on capital and human capital in the models with fixed effects are very close to parameters estimated by Klenow and Rodriguez-Clare (1997) and Hall and Jones (1998) when they calibrate a growth model using microeconomic evidence on the private returns to capital and human capital. If there were reverse causality in the data we would expect our coefficient estimates to be biased upwards, as higher incomes leads to higher stocks of both physical and human capital. The apparent lack of upward bias suggests that reverse causality may not in fact be a problem in our estimates. Upward bias in our results could be present if the aggregate social returns-to-capital were lower then the private returns, that is, if the true coefficients on capital incorporate negative externalities of capital in production; however, this seems unlikely.

We now turn to our estimates of the production function including infrastructure capital. These are reported in table 4 . Insisting that every country has complete coverage of all the variables, over the same period, reduces cross section coverage alarmingly due to gaps in the infrastructure data. Instead we select countries with at least 20 years of complete data over the period 1960-90. We end up with an unbalanced panel containing 57 countries. We use 2 lags and one lead of our capital stock growth rates to allow for short-run effects. This is the longest lag structure possible given our data; each lag uses up five degrees of freedom in each country (we must calculate one extra coefficient per country for each of our five capital stock variables) so an extra lag and lead would completely exhaust our degrees of freedom. However, the results in table 3 suggest that adding extra lags and leads does not change the results very much.

In the first column of table 4 we report results for the full sample. We estimate the long-run variance covariance matrix (again using a Bartlett kernel with a lag truncation parameter of 3 ) to produce consistent $t$-ratios. It is important to do this; naive $t$ ratios, 
calculated using the usual techniques appropriate for stationary data, vastly overstate the significance of the results.

Table 4. The Production Function with Infrastructure (dependent variable: log GDP per worker 1960-90)

\begin{tabular}{|c|c|c|c|}
\hline & Full sample & $\begin{array}{c}\text { Lower-income } \\
\text { countries }\end{array}$ & $\begin{array}{l}\text { Higher-income } \\
\text { Countries }\end{array}$ \\
\hline Total factor productivity & $\begin{array}{l}\text { Year dummies, } \\
\text { fixed effects }\end{array}$ & $\begin{array}{l}\text { Year dummies, } \\
\text { fixed effects }\end{array}$ & $\begin{array}{l}\text { Year dummies, } \\
\text { fixed effects }\end{array}$ \\
\hline Short-run dynamics & 2 lags, 1 lead & 2 lags, 1 lead & 2 lags, 1 lead \\
\hline Log capital per worker & $\begin{array}{c}0.371 \\
(9.65)\end{array}$ & $\begin{array}{c}0.378 \\
(6.56)\end{array}$ & $\begin{array}{r}0.329 \\
(2.85)\end{array}$ \\
\hline Log human capital per worker & $\begin{array}{r}0.087 \\
(2.26)\end{array}$ & $\begin{array}{r}0.095 \\
(1.18)\end{array}$ & $\begin{array}{r}0.005 \\
(0.04)\end{array}$ \\
\hline Log telephones per worker & $\begin{array}{r}0.144 \\
(3.74)\end{array}$ & $\begin{array}{r}0.139 \\
(3.18)\end{array}$ & $\begin{array}{r}0.257 \\
(3.13)\end{array}$ \\
\hline $\begin{array}{l}\text { Log electricity generating } \\
\text { capacity per worker }\end{array}$ & $\begin{array}{r}0.035 \\
(0.91)\end{array}$ & $\begin{array}{r}0.058 \\
(1.59)\end{array}$ & $\begin{array}{r}-0.052 \\
(0.80)\end{array}$ \\
\hline $\begin{array}{l}\text { Log transportation routes per } \\
\text { worker }\end{array}$ & $\begin{array}{r}-0.028 \\
(0.73)\end{array}$ & $\begin{array}{r}-0.050 \\
(0.88)\end{array}$ & $\begin{array}{r}0.174 \\
(1.86)\end{array}$ \\
\hline Countries & 57 & 28 & 29 \\
\hline Observations & 1,348 & 685 & 663 \\
\hline
\end{tabular}

Note: $t$-ratios in parentheses are calculated based on the long-run auto-covariance matrix and are asymptotically $\mathrm{N}(0,1)$.

The coefficients on electricity generating capacity and transportation routes per worker are small and statistically insignificant. These results do not imply that electricity generating capacity and transport routes do not matter, only that they appear to have average productivity level of overall investment. Our investment figures cover all investment, including investment in infrastructure. It follows that our infrastructure capital appears twice in the production function, once by itself and once as a part of total physical capital as explained in section 2 . The correct interpretation of the coefficient on our infrastructure variables is therefore that they represent the output effect of increasing infrastructure capital while holding overall physical capital constant. That is, we measure the effect as an increase in infrastructure, assuming an equal (measured in terms of the cost of investment) offsetting decrease in other forms of capital. Such an offset change will have no impact if the marginal productivity of infrastructure capital is the same as that of other capital.

On the other hand, we find a large, statistically significant, impact of telephones on output. This suggests that investment in telephones is more productive than investment on average, by a substantial margin. This suggests that there may be large externalities to telephones. 
There may well be a great deal of heterogeneity in the sample. In this paper we investigate possible heterogeneity by splitting the sample into two groups of countries based on their level of income per worker in 1960. The results for the two groups are reported in column (2) and column (3) of table 4. The estimates are quite similar across the two groups. Human capital is not statistically significant in either group of countries, but this may just be because the sample size is smaller than for the pooled data. Telephones per worker remain positive and significant in both regressions. For the more developed countries there is also evidence of a positive effect of the provision of transport routes on output, though only at the 10 percent significance level.

\section{Conclusion}

The estimation of an aggregate production function using panel data should take account of the non-stationary nature of the output per worker and capital per worker. Modeling the production function as a long-run relationship that holds worldwide, though with different levels of total factor productivity across countries, we can derive estimates that are robust to reverse causality. Our estimates suggest that the returns to physical capital as a whole, human capital, electricity generating capacity and transport routes are close to those found from microeconomic evidence based on the private returns to these factors or cost benefit analysis. However, we find a large productivity effect of telephone networks over and above the normal productivity of capital, and some evidence that the returns to transport routes are higher than those of other types of capital in the developed countries.

\section{References}

Arellano, M., and O. Bover. 1995. "Another Look at the Instrumental Variable Estimation of Error-Components Models." Journal of Econometrics 68: 29-52.

Aschauer, D.A. 1989, "Is Public Expenditure Productive." Journal of Monetary Economics 23: 177-200.

Barro, R. J., and J. W. Lee. 1993. "International Comparisons of Educational Attainment." Journal of Monetary Economics 32: 363-94.

Bond S., A. Hoeffler, and J. Temple. 1999. "GMM Estimation of Empirical Growth Models." Hertford College, Oxford. Processed.

Canning, David. 1998. "A Database of World Stocks of Infrastructure, 1950-1995." World Bank Economic Review 12(3): 529-47.

Canning, David, and P. Pedroni. 1999. "Infrastructure and Long-Run Economic Growth." Queen's University of Belfast. Processed.

Caselli, F., G. Esquivel, and F. Lefort. 1996. "Reopening the Convergence Debate: A New Look at Cross-Country Growth Empirics." Journal of Economic Growth 1: 363-89. 
Chari, V. V., P. J. Kehoe, and E. R. McGratten. 1996. "The Poverty of Nations: A Quantitative Exploration." NBER Working Paper No. 5414. National Bureau of Economic Research, Cambridge, Mass.

Garcia-Mila T., T. J. McGuire, and R. H. Porter. 1996. "The Effect of Public Capital in StateLevel Production Functions Reconsidered." Review of Economics and Statistics: 177-180.

Gramlich, E. M. 1994. "Infrastructure Investment: A Review Essay." Journal of Economic Literature XXXII: 1176-96.

Hall, R., and C. Jones. 1998. "Why Do Some Countries Produce So Much More Output Per Worker Than Others?" NBER Working Paper No. 5812 (November). National Bureau of Economic Research, Cambridge, Mass.

Holtz-Eakin, D. 1994, "Public Sector Capital and the Productivity Puzzle." Review of Economics and Statistics 76: 12-21.

Hulten, C. R. 1997. "Infrastructure Capital and Economic Growth: How Well You Use It May Be More Important Than How Much You Have." University of Maryland. Processed.

Im, K. S., M. H. Pesaran, and Y. Shin. 1995. "Testing for Unit Roots in Heterogeneous Panels." Department of Applied Economics, Cambridge University. Processed.

Islam, N. 1995. "Growth Empirics: A Panel Data Approach." Quarterly Journal of Economics CX: $1127-70$.

Kao, C. 1997. "Spurious Regression and Residual-Based Tests for Cointegration in Panel Data." Syracuse University. Processed.

Kao, C., and M. H. Chiang. 1997. "On the Estimation and Inference of a Cointegrated Regression in Panel Data." Syracuse University. Processed.

Klenow, P. J., and A. Rodriguez-Clare. 1997. "The Neoclassical Revival in Growth Economics: Has it Gone Too Far?" Graduate School of Business, University of Chicago. Processed.

Mankiw N. G., D. Romer, and D. N. Weil. 1992. "A Contribution to the Empirics of Economic Growth." Quarterly Journal of Economics 107: 407-37.

Pedroni, P. 1997. "Panel Cointegration; Asymptotic and Finite Sample Properties of Pooled Time Series Tests, with an Application to the PPP Hypothesis: New Results." Indiana University. Processed.

Pierse, R. G., and A. J. Snell. 1995. "Temporal Aggregation and the Power of Tests for a Unit Root." Journal of Econometrics 65: 333-45.

Psacharopoulos, G. 1985. "The Returns to Education: A Further International Update and Implications." Journal of Human Resources 14: 584-604.

Psacharopoulos, G. 1994. "Returns to Investment in Education: A Global Update." World Development 22: 1325-43.

Prescott, E. 1998. "Needed, A Theory of Total Factor Productivity." International Economic Review 39(August): 525-51.

Pritchett, Lant. 1996. "Mind Your P's and Q's, The Cost of Public Investment is Not the Value of Public Capital." Policy Research Working Paper No. 1660. Development Research Group, World Bank, Washington, D.C.

Summers, R., and A. Heston. 1991. "The Penn World Table (Mark 5): An Expanded Set of international Comparisons, 1950-1988," Quarterly Journal of Economics CVI:327-36.

World Bank. 1994. World Development Report 1994: Infrastructure for Development. New York: Oxford University Press. 


\section{Policy Research Working Paper Series}

Title

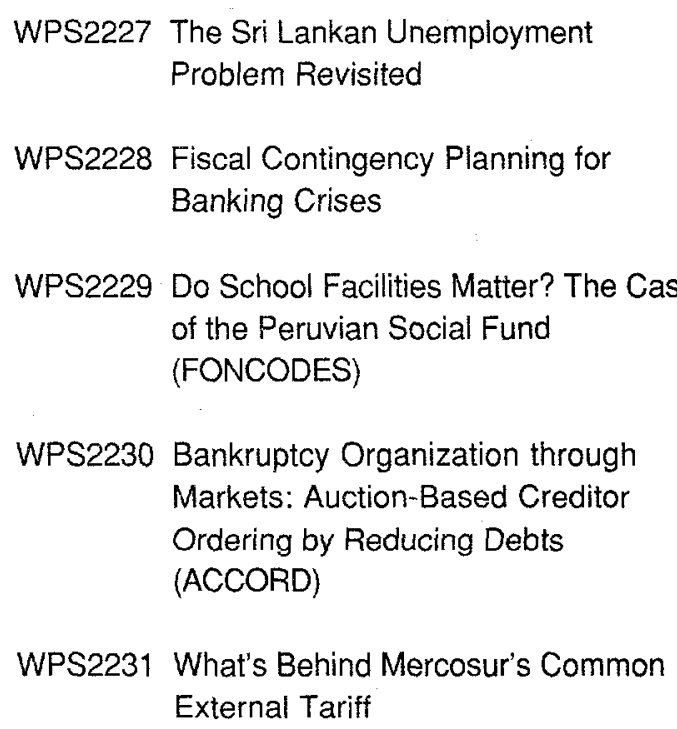

WPS2232 Market Access Advances and Retreats: The Uruguay Round and Beyond

WPS2233 User's Guide to an Early Warning System for Macroeconomic Vulnerability in Latin American Countries

WPS2234 The Green Revolution and the Productivity Paradox: Evidence from the Indian Punjab

WPS2235 Beyond Capital Ideals: Restoring Banking Stability

WPS2236 Valuing Water for Chinese Industries: A Marginal Productivity Assessment

WPS2237 Reforming Tax Systems: The World Bank Record in the 1990s

WPS2238 A Review of the Role and Impact of Export Processing Zones

WPS2239 The EU Factor in the Trade Policies of Central European Countries
Author

Martin Rama

Patrick Honohan

Christina Paxson

Norbert Schady

David Hausch

S. Ramachandran

Marcelo Olarreaga

Isidro Soloaga

L. Alan Winters

J. Michael Finger

Ludger Schuknecht

Santiago Herrera

Conrado Garcia

Rinku Murgai

Gerard Caprio Jr.

Patrick Honohan

Hua Wang

Somik Lall

Luca Barbone

Arindam Das-Gupta

Luc De Wulf

Anna Hansson

Dorsati Madani

Bartlomiej Kaminski
Date

November 1999

November 1999

November 1999

November 1999

November 1999

November 1999

November 1999

November 1999

November 1999

November 1999

November 1999

November 1999

November 1999
L. Tsang

80516

C. Garcia

87969

Contact for paper

S. Fallon 38009

A. Yaptenco 38526

N. Schady 88247

L. Tabada 35555

L. Tabada 35555

M. Fernandez 33766

A Yaptenco 38526

R. Yazigi 37176

L. Barbone 32556

\section{Tabada} 36896

L. Tabada 36896 


\section{Policy Research Working Paper Series}

\section{Title}

WPS2240 The Effects of Land Registration on Financial Development and Economic Growth: A Theoretical and Conceptual Framework

WPS2241 How Land Registration Affects Financial Development and Economic Growth in Thailand

WPS2242 Confronting Competition: Investment Response and Constraints in Uganda

WPS2243 Designing Pro-Poor Water and Sewer Concessions: Early Lessons from Bolivia

WPS2244 True World Income Distribution, 1988 and 1993: First Calculations, Based on Household Surveys Alone

WPS2245 Opportunities for Improving Environmental Compliance in Mexico

\section{Author}

Frank F. K. Byamugisha

Frank F. K. Byamugisha

Ritva Reinikka

Jakob Svensson

Kristin Komives

Branko Milanovic

Susmita Dasgupta
Date

November 1999

November 1999

E. Gelos 37846

Contact for paper

E. Gelos

37846

November 1999

H. Sladovich 37698

November 1999

M. Salehi

37157

November 1999

P. Sader 33902

November 1999

Y. D'Souza 31449 